\title{
ПРОСТОРОВА ЛОКАЛІЗАЦІЯ АКУСТИЧНИХ ПОДІЙ В ЕЛЕКТРОННІЙ МУЗИЦІ: ДОСВІД ДОСЛІДЖЕННЯ
}

\begin{abstract}
Мета роботи - дослідити просторову локалізачію акустичних подій в електронній музиці. Для досягнення иієё мети ставимо такі завдання: обтрунтувати поняття просторової локалізації акустичних подій, розглянути методи аналізу та дослідити роль просторової локалізаиї як засобу виразності на прикладі творів украӥнських композиторів. Методи - під час дослідження використано інструменти панорамного аналізу музичних творів за допомогою програмного забезпечення. Результати панорамного аналізу було піддано системно-аналітичному й компаративному методам дослідження. Наукова новизна - у статті вперше описано застосування панорамного аналізу для вивчення творів акустичної музики, обтрунтовано застосування терміна «мізанфонія» (Г. Ганзбург) щодо творів електронної музики, уперше досліджено роль просторових ефектів на прикладах творів Олександра Несторова та Алли Загайкевич. Висновки Показано, щзо за допомогою сучасного інструментарію композитори можуть вільно локалізувати акустичні подї за панорамою, до того ж локалізація може бути як статичною, так $і$ динамічною - в останньому випадку створюється ефект рухомого об'єкта. Показано, що просторова локалізачія акустичних подій піддається аналізу за допомогою відповідного інструментарію, зокрема широкі можливості демонструє інструмент «панорамний дисплей» (spectral pan display) у програмі Adobe audition 3.0. Аналіз творів О. Несторова та А. Загайкевич показує, щзо в простіших випадках просторові ефекти можуть застосовуватися для створення відчуття об'ємного простору, у складніших - задля досягнення більшої ясності звукового матеріалу. Також на просторові ефекти можуть покладатися драматургічні функиї, у иьому випадку просторова локалізація звукових подій характеризується високим ступенем диференціачіі. Специифічним прийомом є створення рухомих звукових об'єктів, щз переміщуються в просторі на тлі решти відносно статичних елементів музичної фактури. Багатоманіття прийомів просторової організації акустичних подій запропоновано називати терміном «мізанфонія».
\end{abstract}

Ключові слова: електронна музика, аналіз музичних творів, акустика, спектральний аналіз, просторові ефекти, локалізація звуку.

Andriy BONDARENKO, orcid.org/0000-0002-6856-991X Concertmaster at the Music Art Department Kyiv National University of Culture and Arts (Kyiv, Ukraine) bondareandre@gmail.com

\section{SPATIAL LOCALIZATION OF ACOUSTIC EVENTS IN ELECTRONIC MUSIC: RESEARCH EXPERIENCE}

Objective of the study is to investigate the spatial localization of acoustic events in electronic music. To achieve this goal we set the following tasks - to consider the concept of spatial localization of acoustic events, to consider methods of analysis and to explore the role of spatial localization as a means of expression on the example of works by Ukrainian composers. Methodology - the tools of panoramic analysis of musical works with the help of software were used. The results of the panoramic analysis were subjected to system-analytical and comparative research methods. Scientific novelty - the article describes the use of panoramic analysis for the analysis of acoustic music, substantiates the use of the term "misanphony" (G. Hanzburg) in relation to works of electronic music, for the first time explores the role of spatial effects on the works by Olexander Nestorov and Alla Zagaykevich. Conclusions. The use of the modern instruments allows composers to localize acoustic events in the panorama. Localization of sound objects can be either static or dynamic - in the latter case, the effect of a moving object is created. It is shown that the spatial localization of acoustic events can be analyzed by appropriate tools; in particular, the tool "Spectral Pan Display" in Adobe audition 3.0 demonstrates a wide range of possibilities. Analysis of the works of $O$. Nestorov and A. Zagaykevych shows that in simpler cases, spatial effects can be used to create a feeling of three-dimensional space, in more complex - to achieve greater clarity of sound material. Also spatial effect could perform dramatic functions; in this case, the spatial localization of sound events is characterized by a high degree of differentiation. Another specific technique is creating sound objects moving in a space against the background of other relatively static elements of the musical texture. The variety of methods of spatial organization of acoustic events is proposed to be called the term "misanphony".

Key words: electronic music, analysis of musical works, acoustics, spectral analysis, spatial effects, sounds localization. 
Постановка проблеми. Електронна музика внаслідок своєї специфіки має низку особливостей, що були не притаманні або майже не притаманні музиці інструментальній i вокальній. Насамперед ідеться про класичні чотири параметри звуку - звуковисотність, тембр, динаміку і тривалість. В електронній музиці ці параметри мають дещо інакший вигляд - так, звуковисотність і тембр зазвичай розглядають у комплексі, використовуючи термін «спектр звуку», динаміка розглядається як амплітуда звукового сигналу, а поняття тривалості звуку ускладнюється визначенням поняття акустичної події або звукового об'єкта, що $\epsilon$ предметом окремих досліджень. Проте для аналітичних цілей необхідно додати ще один важливий параметр - просторову локалізацію звукового об'єкта. Якщо в класичній музиці минулих епох просторова локалізація звуку була предметом уваги композиторів лише у виняткових випадках, то для творців електронної музики питання просторової локалізації стає предметом спеціальної уваги. Ця обставина спонукає нас до спеціального дослідження, присвяченого питанням просторових ефектів та їхньої ролі в електронній музиці.

Аналіз досліджень. Ролі просторових ефектів у музиці присвячена робота Г. Ганзбурга, що, зі свого боку, грунтується на наукових працях С. Бібіка, Е. Курта, С. Езенштейна, I. Барсової, Л. Ноно. Іновативним у цій роботі є обгрунтування терміна «мізанфонія», що видається особливо перспективним для досліджень електронної музики. Методологічною опорою нашого дослідження $є$ також роботи П. Шеффера, Д. Смоллі, М. Шіона та Г. Когута, у яких обгрунтовано поняття «звукового об'єкта» або «акустичної події» як елементарного конструктивного елемента музичної тканини. Особливий інтерес також становлять дослідження Ф. Отондо щодо цілей застосування просторових ефектів композиторами Західної Європи.

Водночас значний обсяг питань, пов'язаних із властивостями й типологією акустичних подій, залишається недослідженим. Одним із них $є$ питання просторової локалізації, або «мізанфонії» акустичних подій, як спеціального засобу виразності, що його застосовують композитори автори електронної музики.

Мета статті - дослідити просторову локалізацію акустичних подій в електронній музиці. Для досягнення цієї мети ставимо такі завдання: обгрунтувати поняття просторової локалізації акустичних подій, розглянути методи аналізу та дослідити роль просторової локалізації як засобу виразності на прикладі творів українських композиторів.
Виклад основного матеріалу. Звуковий матеріал електронної музики, на відміну від класичної інструментальної або вокальної, зазвичай не фіксується в нотному записі й навіть більше - не може бути зафіксований принципово через специфіку самого звукового матеріалу. Якщо в інструментальній музиці елементарним конструктивним елементом $€$ нота, що має свою зафіксовану графічно звуковисотність і тривалість, то в електронній музиці таким конструктивним елементом $\epsilon$ «акустична подія» або «звуковий об’єкт».

Термін «звуковий об'єкт» ввів П'єр Шеффера у «Трактаті про музичні об’єкти», пояснивши його як «одиницю, еквівалентну одиниці дихання чи артикуляції, одиницю гри на музичному інструменті; [...] акустичний акт та інтенцію слухання» (Chaeffer, 2017). Докладніше пояснення цього поняття дає Майкл Шіон: «Поняття звукового об'єкта стосується будь-якого звукового феномену або події, що сприймається як цілісна сутність і може бути почута під час цілеспрямованого прослуховування, незалежно від походження чи змісту. Звуковий об'єкт співвідноситься саме 3 цілеспрямованим прослуховуванням: він існує не сам собою, а в контексті цілісного задуму. Це звукова одиниця, що сприймається в іiі матеріалі, особливій фактурі, власних якостях і вимірах сприйняття. 3 іншого боку, сприйняття цієї цілісності зберігає ідентичність під час різних прослуховувань, така організована цілісність може бути співставлена 3 поняттям «гештальту» у психології» (Chion, 1983: 32).

В українському музикознавстві аналогічний за сутністю термін «акустична подія» запропонував Г. Когут. Дослідник визначає акустичну подію як «будь-яке акустичне явище, яке відображається в нашій свідомості згідно з критеріями цілісності, а також вирізняється наявністю нових зв'язків 3 іншими елементами системи» (Когут, 2003: 60). Хоча Г. Когут і не посилається на роботи П. Шеффера, сутнісна ідентичність цих термінів, на нашу думку, є очевидною - в обох випадках ідеться про елементарні конструктивні одиниці (Г. Когут також використовує метафору «акустичний квант»), які, будучи об'єднані системою зв'язків, утворюють музичну цілісність твору.

У попередніх роботах (зокрема, у дослідженні твору А. Загайкевич «Мотус», (Бондаренко, 2015)) ми розглядали акустичні події переважно 3 погляду їхніх спектральних характеристик, які можна розглядати як відповідник звуковисотності й тембру в класичній музиці. Натомість вважаємо за необхідне виділити й інший аспект акустичних подій - їхню просторову локалізацію. 
Просторова локалізація звуку в окремих випадках була предметом особливої уваги композиторів минулих століть. Техніку організації просторової реальності Г. Ганзбург пропонує називати мізанфонією, охоплюючи цим терміном «усі явища, що залежать від просторового розташування джерел звуку і від їх переміщення стосовно одне одного і щодо слухача» (Ганзбург, 2020: 33). Дослідник показує, що техніка мізанфонічних прийомів лежить в основі формування жанру concerto grosso, якому властиві просторово-динамічні зіставлення зіставлень, які «лише поступово починали доповнюватися зіставленнями тембрів» (Ганзбург, 2020: 34). Схожий підхід спостерігався і в багатохорних концертах раннього бароко (зокрема, й українських авторів - I. Домарацького i М. Дилецького). В епоху романтизму композитори інколи спеціально передбачали розташування окремих інструментів або груп інструментів у відносно віддалених пунктах або в різних кутах зали. Один із показових прикладів - «Те Deum» Г. Берліоза, для виконання якого передбачено чотири оркестри різних складів, розташовані по різні боки від слухача. Звернення до мізанфонії знаходимо і в творах сучасних українських композиторів. Як приклад, наведімо твори В. Рунчака: «Труби Єрихону» передбачають розташування 12 трубачів по всьому периметру концертної зали, а «Нагірна проповідь» - розділення артистів хору по чотирьох групах, що розташовуються в різних кінцях зали, утворюючи форму хреста.

Водночас у вокально-інструментальній музиці мізанфонія має очевидні обмеження. По-перше, різні концертні зали мають різну акустику й різні можливості для розміщення музикантів за межами сцени, тож просторові ефекти, передбачені для виконання твору в одній залі, можуть не спрацювати в іншій. 3 іншого боку, обмеження стосуються й ефекту переміщення джерела звуку - для досягнення такого ефекту варто було б переміщати самих музикантів під час виконання твору; якщо це й можливо, то тільки на повільних швидкостях, безпечних для самого фізіологічного процесу інструментального чи вокального виконавства.

Сучасні звукозаписні технології забезпечують просторові ефекти за допомогою стереофонії - техніки відтворення звуку з використанням двох або більшої кількості незалежних звукових каналів через систему з двох або більше звуковідтворювальних пристроїв, що розміщуються відповідно ліворуч і праворуч від слухача. Можливості сучасних технологій у створенні просторових ефектів надзвичайно багатоманітні й описані у відповідній технічній літературі. Зокрема, просторова локалізація є найпростішим із такого роду ефектів і з технічного погляду полягає в забезпеченні різної амплітуди звучання у правому і лівому каналах. У звукових редакторах відношення між цими амплітудами називається «панорамою» й вимірюється у відсотках - від 0\% (амплітуда у лівому і правому каналі однакова, звук сприймається по центру) до 100\% (звуковий сингал локалізуються суто в одному з каналів).

Під час аналізу звукового запису просторова локалізація акустичних подій може бути досліджена шляхом слухового аналізу та різними методами інструментального аналізу. Слуховий аналіз дає змогу вивчити просторові ефекти в першому наближенні - зазвичай автор твору намагається створити просторові ефекти максимально рельєфними, завдяки чому вже слуховий аналіз дає змогу зробити попередні висновки. Серед інструментальних методів вивчення перелічимо основні. Вивчення спектрограми за допомогою інструментів, які ми показували в попередній роботі (Бондаренко, 2015), дають змогу диференціювати та вивчити окремі акустичні події та їх взаємодію у музичній тканині твору. Водночас акустичні події, локалізовані по краях панорами, матимуть різну інтенсивність у лівому і правому каналах, або навіть присутні лише в одному з каналів, що також дає змогу зробити з певним наближенням висновок про просторову локалізацію цих подій. Аналогічний наближений висновок можна зробити під час порівняння осцилограми лівого i правого каналів - більша амплітуда на одному 3 каналів свідчитиме про відповідну просторову локалізацію звуку. В окремих випадках корисну інформацію може надати спектральний аналіз, представлений різнокольоровими лініями для лівого і правого каналів - розбіжність цих ліній свідчитиме про відповідну локалізацію окремих частотних компонентів.

Нарешті, окремі програми пропонують і спеціальний інструмент панорамного аналізу, що дає змогу визначити просторову локалізацію 3 великою точністю. У різних програмах цей інструмент має свою назву - «панорамний дисплей» (spectral pan display) в програмі Adobe audition 3.0, або «стерео план» (stereo plan) у програмі Sonic Visualiser, або «стерео азимут» (stereo azimuth) в програмі Sonic Lineup. Як і спектрограма, панорамний дисплей представляє аудіозапис у вигляді двовимірного простору, у якому вісь $\mathrm{X}$ - часова, а вісь Y - локалізація звуку від 100\% ліворуч (L100\%) до 100\% праворуч (R100\%), водночас інтенсивність (яскравість) спектральних ліній відображає інтенсивність (амплітуду) 
відповідного сигналу. У програмі Adobe audition 3.0 панорамний дисплей містить також інформацію про частоти - звукові сигнали різної частоти представлені різними кольорами - від синього для низьких частот до червоного і темно-рожевого - для високих. Натомість у програмах Sonic Visualiser та Sonic Lineup така інформація не відображається - колір спектральних ліній не залежить від частоти звукового сигналу.

Мета застосування просторових ефектів творцями електронної музики може бути різною. Опитування серед композиторів-електронників, проведене Ф. Отондо в 2006 році, показало, що самі композитори називають такі найбільш важливі цілі застосування просторових ефектів - «створення звукового матеріалу» (37\%), «рух звуків» $(30 \%)$, «локалізація звуків» $(28 \%)$, «ясність звукового матеріалу» (28\%), «музична структура» $(23 \%)$, «створення в композиції простору» $(23 \%)$, «акустика кімнати» (21\%), «функційна або драматургічна роль» (21\%) (Отондо, 2008). Водночас очевидно, що в певних випадках вказані цілі можуть поєднуватися, а в певних випадках композитор може діяти інтуїтивно і не формулює такі цілі вербально.

Проаналізуємо деякі твори українських автоpiв, що ввійшли до компакт-диска «Electroacoustic works of Ukrainian composers 1964-2017» з погляду характеру використання просторових ефектів.

Історично перший електроакустичний твір В. Гоздяцького «4 домашні скерцо» (1961-1964) просторові ефекти не використовує. Панорамний аналіз показує зосередження всіх звукових подій по центру, що характерно для монофонічних записів. Цілком очевидно, що на початку 1960-х композитор просто не мав можливості здійснити стереофонічний запис (тут доцільно згадати, що в США стереофонічні записи набули поширення наприкінці 1950-х, а в СРСР - тільки у 1962-му був випущений перший стереомагнітофон, що коштував 350 рублів, тож навряд чи був доступний київським музикантам).

Твір О. Несторова «Кольорова фотографія» (1991), що є першим електронним твором у сенсі використання електронних джерел звуку, використовує стереофонію головним чином для створення об'ємного акустичного простору. Переважаючими в цьому творі є акустичні події 3 гармонічними спектрами, їхній панорамний аналіз показує постійні коливання по панорамі переважно в межах відхилення на 50\% ліворуч чи праворуч. Високочастотні звукові кластероподібні об'єкти на частотах 5-8 кГц займають майже весь панорамний простір - такі об'єкти справляють враження одночасної присутності з усіх сторін. I лише звуки, що імітують традиційні ударні інструменти, які з'являються в середній частині твору, мають контрастну локалізацію - звуки великого та робочого барабанів мають локалізацію по центру, хай-хетів - ліворуч, райд-тарілок - праворуч. Отже, у цьому творі функція просторових ефектів - це переважно створення акустичного простору і лише частково - локалізація звуків.

Твір «Мотус» А. Загайкевич (2003) вирізняється переважанням акустичних подій із негармонічними спектрами, до того ж на початку твору переважають шумоподібні звуки, надалі з'являються мультифонічні та епізодично - гармонічні звуки. Панорамний аналіз твору показує надзвичайно витончену роботу композитора 3 панорамою. Спостерігаємо такі тенденції роботи 3 панорамою: шумоподібні звукові об'єкти частіше розміщуються по краях панорами (нерідко близько до 100\%), натомість близькі до гармонічних - ближче до центру. На початку твору, коли щільність музичної фактури є низькою, окремі шумові спектри вступають в антифонну взаємодію, з'являючись поперемінно на лівому або правому краях панорами. У міру розширення частотного діапазону акустичні події з різною частотною характеристикою розміщуються в протилежних частинах панорами - низькочастотні в правому, а високочастотні - у лівому, або навпаки (порядок розташування міняється). Починаючи 3 1:05 звучання, композитор залучає «діагональні» об' єкти звукові події, локалізація яких швидко змінюється 3 часом. Наприклад, комплекс акустичних подій на 1:13-1:15 містить одночасне панорамне переміщення від L 86\% до R 98\% і частотне переміщення від 10 кГц до 100 Гц в часовому проміжку до 2 секунд. Такі «діагональні» об'єкти з'являються в творі епізодично, і завдяки органічному зв'язку 3 оточуючим музичним матеріалом сприймаються як епізодичні кульмінаційні моменти розвитку музичної тканини. Найбільш складною панорамна диференціація $€$ в кульмінаційних зонах твору, проте загальна тенденція зберігається частотна контрастність звукових об'єктів підкреслюється розбіжною просторовою локалізацією.

Отже, у цьому творі застосування просторових ефектів $\epsilon$ поліфункційним. Це і ясність звукового матеріалу, і локалізація окремих звуків, і створення рухомих звукових об'єктів, i, нарештідраматургічна функція. У цьому випадку можна говорити про мізанфонію як про спеціальний і детально продуманий засіб музичної виразності. 
Висновки. За допомогою сучасного інструментарію композитори можуть вільно локалізувати акустичні події по панорамі, до того ж локалізація може бути як статичною, так і динамічною - в останньому випадку створюється ефект рухомого об'єкта. У звукозаписах просторова локалізація може бути проаналізована за допомогою відповідного інструментарію, зокрема широкі можливості демонструє інструмент «панорамний дисплей» (spectral pan display) в програмі Adobe audition 3.0.

В окремих випадках просторові ефекти застосовуються для створення відчуття об'ємного простору. В інших випадках просторова локалізація може бути диференційованою - композитор навмисно розосереджує різні акустичні події в акустичному просторі задля досягнення більшої ясності звукового матеріалу й виконання драматургічних функцій. Специфічним прийомом є створення рухомих звукових об'єктів, що переміщуються в просторі на тлі решти відносно статичних елементів музичної фактури. Багатоманіття прийомів просторової організації акустичних подій запропоновано називати терміном «мізанфонія».

Застосування просторових об'єктів потребуватиме подальших досліджень. Зокрема, актуальним залишається завдання вивчення творів електронної музики українських авторів, що належать до різних стильових течій - від експериментальної до танцювальної. Потребуватиме наукового опису й застосування складніших часопросторових ефектів, таких як реверберація, лінії затримки, фленжер, хорус і т. п.

\section{СПИСОК ВИКОРИСТАНИХ ДЖЕРЕЛ}

1. Бондаренко А. Виявлення і аналіз акустичних подій в електронній музиці (на прикладі «Мотус» А. Загайкевич). Питання культурологіï. 2015. № 31. С. 22-28.

2. Ганзбург Г. Просторові ефекти в звучанні музики. Вісник Київського наиіонального університету культури $i$ мистеитв. Серія: Музичне мистеитво. 2020. № 1. С. 27-36.

3. Когут Г. Акустичні феномени як події. Наукові записки Тернопільського педагогічного університету ім. В. Гнатюка. Серія: Мистеитво. 2003. № 1 (10). С. 60-67.

4. Chion, M. Guide des objets sonores. Préface de Pierre Schaeffer. Paris : INA-GRM, Buchet-Chastel, 1983. 187 p.

5. Otondo, F. Contemporary trends in the use of space in electroacoustic music. Organised Sound. 2008. № 13 (1). P. 77-81. DOI: $10.1017 / \mathrm{S} 1355771808000095$.

6. Schaeffer, P. Treatise on musical objects : an essay across disciplines. North, Christine, Dack, John. 2017. Oakland, California.

\section{REFERENCES}

1. Bondarenko A. I. (2015) Vyiavlennia i analiz akustychnykh podii v elektronnii muzytsi (na prykladi "Motus" A. Zahaikevych) [Detection and analysis of acoustic events in electronic music (on the example of "Motus" by A. Zagaykevich)]. Pytannia kulturolohii 31, 22-28. [in Ukrainian].

2. Hansburg G. (2020) Prostorovi efekty v zvuchanni muzyky [Spatial effects in the sound of music]. Bulletin of Kyiv National University of Culture and Arts. Series in Musical Ar, 1, 27-36 [in Ukrainian].

3. Kohut H. (2003) Akustychni fenomeny yak podii [Acoustic phenomena as events]. Nauk. zapysky Ternop. ped. un-tu im. V. Hnatkzha: Seriya: Myst-vo. Ternopil', 1. [in Ukrainian];

4. Chion, M. (1983) Guide des objets sonores. Préface de Pierre Schaeffer. Paris : INA-GRM, Buchet-Chastel, 187 p.

5. Otondo, F. (2008) Contemporary trends in the use of space in electroacoustic music. Organised Sound, 13(1), 77-81. DOI: $10.1017 / \mathrm{S} 1355771808000095$.

6. Schaeffer, P. (2017). Treatise on Musical Objects: An Essay Across Disciplines (Vol. 20). Univ of California Press. 